\title{
Distance Learning Models and Their Effusiveness in Cameroon Higher Education
}

\author{
Fedelis Lekeaka Alemnge \\ Faculty of Education, University of Buea, Buea, Cameroon \\ Email: fedelis.alemnge@gmail.com, alemngelekeaka@outlook.com
}

How to cite this paper: Alemnge, F. L. (2018). Distance Learning Models and Their Effusiveness in Cameroon Higher Education. Creative Education, 9, 791-817. https://doi.org/10.4236/ce.2018.95059

Received: July 20, 2017

Accepted: April 24, 2018

Published: April 27, 2018

Copyright $\odot 2018$ by author and Scientific Research Publishing Inc. This work is licensed under the Creative Commons Attribution International License (CC BY 4.0).

http://creativecommons.org/licenses/by/4.0/

\begin{abstract}
This study investigated the distribution and effectiveness of distance learning models in selected higher education institutions in Cameroon. The specific objectives of the study were: (1) to identify the distance learning models currently in use in higher education worldwide, (2) to identify and describe the models currently used in selected Cameroon higher education institutions, and (3) to assess the effectiveness with which each institution applies its distance learning model. The design of the study was a survey, based on the cross-section survey. The participants in this study were made up of 97 respondents from Distance Learning (DL) programmes in the universities of Buea, Douala, Dschang and Yaounde I. Data were collected from literature and a close ended questionnaire, designed using the Likert method. Content analysis was carried out through literature review. The design facilitated a comparison of indicators among the distance learning programmes of the four institutions concerned. The quantitative data were subjected to descriptive and inferential statistical analysis using the Statistical Package for the Social Sciences (SPSS) Version 17.0 (SPSS Inc. 2008). Descriptive statistics were used to present the distribution of subjects between and within subsets using frequencies, proportions, cross tabulations and Multiple Responses Analysis. The results of the study indicate that in general terms, higher education institutions worldwide use at least seven models in distance learning programmes. Cameroon higher education institutions on their part are using mainly the Multi-media, and the Telelearning models of distance learning. In relation to effectiveness, all the distance learning programmes are reported to be satisfactorily providing students with pre-registration information, information relating to the content of courses, and motivational strategies that reduce the student dropout rate. However, students in all the distance learning programmes reported dissatisfaction with interaction.
\end{abstract}




\section{Keywords}

Distance Learning Models, Effectiveness of Models, Cameroon Higher

Education

\section{Introduction}

In the past two decades, higher education in Cameroon has undergone many changes in an effort to respond to a number of major challenges: limited access and insufficient diversity in provision of tertiary education, gender parity, reduced funding, quality assurance and good governance. These changes arose from increasing pressures to respond to market forces and technological opportunities with limited resources and the competitive climate imposed by globalization, technological changes, and the ever changing needs and demands of society. One of the major areas of reform has been the introduction and development of distance learning initiatives.

In this connection, the Ministry of Higher Education in Cameroon has contributed to the development of distance learning in Cameroon through several initiatives which included the initiation and promotion of the "one teacher, one computer" policy (aimed at developing the computing skills of teachers and enabling each to own a computer), "beginning of the pioneer DE programme in the Dschang University Centre, the creation of the CITI and electronic library in Yaounde; training of teachers of higher education in China in distance learning; launching of a Master's of Distance learning programme for Public Universities (granted to the University of Douala for execution); starting of a myriad of DE programmes in Institute Universitaire de Technologie (IUT) Bandjounm, University of Yaounde I (UYI), University of Buea (UB) and the University of Douala (UDL); and the start of the Virtual University of Central Africa.

Consequently, the Dschang University Centre created in 1991, with funding from the Canadian International Development Agency (CIDA), and the collaboration of the University of Guelph, Canada, a distance learning programme with the aim of providing students the opportunity of learning while working. The rationale of the programme was based on the fact that for Cameroon to move out of the traditional system of peasant agriculture into a dynamic, viable market-oriented and sustainable agriculture, it needed well trained and efficient middle-level staff. The main objective was to provide access to the many Cameroonians who wanted university education in agriculture but could not access the University Centre due to restrictive admission procedures and practices as well as lack of accommodation and funding.

A national forum entitled: National Forum on Distance learning (Forum National sur l'Enseignement $\grave{\alpha}$ Distance) was held in Yaoundé from the $16^{\text {th }}$ to $19^{\text {th }}$ of September 2003 on "Distance learning: An alternative for increasing diversity, to access and to quality in education". This forum was jointly organized by the 
Ministries of National, Technical and Vocational Training and Higher Education under the aegis of the Commonwealth of Learning. The main objective of the forum was to open dialogue among all stakeholders on the national needs, priorities and challenges in the design and implementation of Open and Distance Learning (ODL) in Cameroon and to propose to Government elements of a national strategy or road map for the implementation of distance learning.

Following this conference, state universities started initiating and engaging in collaborative ventures to gather experience to enable them eventually initiate and implement distance learning programmes. This study will therefore, investigate the distance learning programmes initiated in higher education as a result of the foregoing actions to determine their modes of operation and to assess how effectively they are operating in the delivery of their programmes.

In this connection, the University of Douala participated in the "Projet Virtuel au Service de l'Afrique Francophone" from 2005 to 2008 and initiated its own programme in partnership with the Université de Pariset Marne la Villéand the Ecole Nationale de Sciences Geographiques, Paris.

The University of Yaounde I started its own programme in Electrical Engineering and Telecomunications in partnership with the Agence Universitaire de la Francophnie (AUF) in the 2006/2007 academic year. The programme is housed by the Department of Electrical and Telecommunications Engineering of the l'Ecole Nationale Supérieure Polytechnique (ENSP). It is a postgraduate programme aimed at providing students with skills and competences to conceive and install various telecommunications devices.

The University of Buea also started a distance learning programme in the 2007/2008 academic year. The B. Ed. programme in Nursery and Primary Education seeks to upgrade the knowledge and skills of primary school teachers with opportunity to earn a Bachelor degree in Nursery and Primary Education. It is hoped that through this in-service training, practising teachers should acquire new skills for teaching and managing the ever increasing school enrolment, demands and complexities.

The universities of Ngoundere and Yaounde II have not initiated any distance learning programes of their own. However, they are in an apprenticeship stage having started in the 2009/2010 academic year, to work in partnership with l'Association Universitaire de la Francophonie (l'AUF). The universities of Ngaoundere and Yaounde II assist l'AUF in the provision of pre-registration information to prospective students, and host a study centre equipped with an internet connection, reading space and an electronic and paper library for registered students.

\subsection{Statement of the Problem}

Distance learning has been one of the media of delivering educational programmes for many years. The system was in use in Cameroon since the later part of the colonial period, where metropolitan institutions delivered pro- 
grammes through correspondence courses based on printed texts. With the development of an application of ICTs in education, distance learning acquired new and sophisticated means of delivering its courses to masses of learners across the globe. This led several countries which were experiencing difficulties in providing education to their citizens to take the opportunities offered by this mode of learning to increase access and equity.

Student enrollment in higher education grew at an annual rate of $9.7 \%$ from 1986 and reached $14,7 \%$ in 1993 causing student enrollment to increase from 19,598 in 1986 to 44,551 in 1993 and then to 120,000 in 2006-2007. This increase in the number of students seeking tertiary education was not accompanied by a corresponding growth in infrastructure and staffing thereby creating a gap between the number of students seeking higher education and the number that could be accommodated. In order to close this gap, the models of distance learning chosen by the nascent DE institutions and the quality of the programmes offered will be critical. This study therefore, seeks to determine the distance learning models adopted by higher education institutions in Cameroon and to examine the effectiveness of their functioning.

\subsection{Purpose of the Study}

To examine models of distance learning and their effectiveness in Cameroon Higher Education.

\subsection{Research Questions}

Based on the preceding discussion the study is guided by the following research questions. These are:

- What are the Distance learning models that are used in higher education worldwide?

- Which of the above models are currently used in DL in Cameroon Higher Higher Education?

- What is the effectiveness of the use of the selected models in each of these institutions?

\subsection{Literature Review}

The theories of Wedemeyer (1971), Peters (1994), Holmberg (1989), and Moore (1991), on Independent study, Industrial production, Didactic conversation, Transaction and Social constructivists theories have and continue to underpin distance learning practice.

Wedemeyer (1977) defines "independent study" in the following terms:

"Independent study consists of various forms of teaching-learning arrangements in which teachers and learners carry out their essential tasks and responsibilities apart from one another, communicating in a variety of ways for the purpose of freeing internal learners from inappropriate class pacings or patterns, of providing external learners with opportunities to 
continue learning in their own environments, and of developing in all learners the capacity to carry on self-directed learning" (Wedemeyer, 1977: p. 1).

We can readily extrapolate from the above definition that independent study involves teaching-learning arrangements which have various forms. Central to these arrangements is the idea that both teachers and learners stay apart from each other while didactic communication goes on in a variety of modes. The main purpose is to facilitate learning for on- and off-campus students, by relieving on-campus students from the customary pacing associated with classroom teaching and providing opportunities for students to learn in their own familiar environments.

However, according to Koul et al. (2000), the important pedagogical aspects of Peters (1994), distance learning address the role of the learner and teachers and the nature of the learner and learner support.

Peters (1994), proposes that educational communication in distance learning is artificial as the entire communication is broken up into components such as print, audio, video, email which are affected mechanically. The effect of breaking up educational communication into the above components has brought about changes in teaching and learning resulting in new responsibilities for teachers and learners. The teacher has become more of a manager charged with the management of a teaching process and teaching materials that are split into many compartments each managed by a different person who make up the system. Garrison (2000: p. 7) notes that though the industrial model had an enormous influence on distance learning, "it was not a theory of teaching nor of learning, but rather a contribution to clear thought about the organization of distance learning".

Holmberg's (1989) theory of distance learning practice is focuses on the concept of "guided didactic conversation" (Holmberg, 1989: p. 43). Though the emphasis here rests on simulated conversation, it nevertheless also refers to real conversation. This "friendly conversation" is embedded into the content of "well-developed self-instructional (written course) materials (resulting in) feelings of personal relations... intellectual pleasure (and) study motivation" (Holmberg, 1989: p. 43). While acknowledging that the communication between the students and the distant tutor has essential tasks, he suggests that this conversation is by economic necessity, supplemented to the pre-produced course.

Moore (1991) presents an insightful and analytical model that builds on the perceived limitations of the independent learning packages. According to Moore (1991), transactional distance is pedagogic, not geographic and calls for 'special organisation and teaching procedures composed of two variables, "structure" (individualization) and "dialogue" (Moore, 1990; Moore \& Kearsley, 1996). In this conception, structure refers to the way a course is designed. This is usually done in relation to the way teaching is organised and the teaching materials used. Conversely, dialogue is associated with the medium of communication and 
may include either real two-way communication or Holmberg's internal didactic communication. This "dialogue" may take place in a face-to-face situation, by individual or group telephone, individual or group correspondence, computer assisted instruction or may be mainly one sided; as in the case of programmed instruction, television, radio and text materials (Koul et al., 2000).

The socio-cultural theory describes learning as a social process and argues that human intelligence has it roots in society or culture (Vygotsky, 1978). The major theme of his theoretical framework is that human interaction is at the heart of the development of cognition. Vygotsky believes that "every function in the child's cultural development appears twice; first, on the social level and later, on the individual level; first between people (interpsychological) and then inside the child (intrapsychological). This applies equally to voluntary attention, to logical memory, and to the formation of concepts. All the higher functions originate as actual relationships between individuals" (Vygotsky, 1978: p. 57).

Vygotsky's theory postulates that the potential for learning is limited to a "zone of proximal development" (ZPD). The "zone" represents the area of exploration for which the child is cognitively ready but needs help and social interaction to fully develop (Briner, 1990), A more experienced peer or teacher can provide the learner with "scaffolding" to support the learner's evolving understanding of development of complex skills. Vygotsky's theory suggests the use of strategies such as modeling, discourse, scaffolding and collaborative learning to support learners in facilitating intentional learning.

Norman (1993) corroborates the process of learning advocated by Vygotsky but argues that the process occurs in the reverse order. That is, the process of articulation and reflection involves first, internal negotiation and second, social negotiation that we debate, wrestle, and argue with ourselves over what is correct, and then we negotiate with each other over the correct meaning of ideas or events. Norman (1993) agrees that meaning is the understanding that arises from the above processes and the application of the meaning in real-life is what he refers to as "experiential knowledge".

Brown, Collins and Duguid (1989) note that "situated learning" uses apprenticeship, coaching, collaboration, authentic context, tasks, activities, and cognitive tools. The theory of situated cognition has as its basis the provision of authentic context for the leaner, and fostering social interaction and collaboration among learners in the learning environment. According to Lave (1988), learning is seen as a function of the activity, the context and the culture in which it takes place, in contrast to classroom learning which is abstract and out of context.

\section{Pedagogical Models of Distance Learning}

A review by Peters (98b.htm) reveals seven pedagogical models of distance learning that are mostly used by institutions of higher learning worldwide to deliver distance learning. These models are used in different countries and regions of the world. This suggests that socio-economic, technological and other factors 
influence the selection of the pedagogical model used in each country. Following is a summary description of each of the models.

\subsection{The Correspondence or Independent Study Model}

This model is based on printed course materials and characterized by postal communication between the institution and students. The model does not promote interaction between tutors and students and among students. It represents the first generation of distance learning.

\subsection{The Multi-Media or Study Centre Model}

The multi-media model of distance learning delivers it programmes through a combination of asynchronous (print, audio and videotapes) and synchronous (interactive video and some computer based learning applications) technology. Face-to-face tutorials also provide interactivity.

\subsection{The Telelearning or Online Learning Model}

This model uses more advanced information and communication's technologies in the delivery of its programmes in order to facilitate a teacher to student and student to student interaction in real time. The interaction is not only audio (audio teleconferencing, autographic communication and radio) but equally audiovisual (video conferencing and broadcast television).

\subsection{The Group Distance Learning Model}

This model uses exclusively radio and television to deliver the content of the distance learning programme to students who attend obligatory classes. There are no specially prepared course materials and students rely on the traditional lecture notes of tutors as obtains in the face-to-face situations in classrooms.

\subsection{The Autonomous Learners' Model}

This model is the most learner-centred among the other models. In this model students determine their learning objectives, select the content, and determine the learning strategies and methods of evaluating their learning. Tutors interact with students through periodic meetings only.

\subsection{The Technologically Extended Classroom Teaching Model}

This model is characterized by the extension of a teacher's lecture in a classroom to two or more classrooms in real time using either cable or satellite television or a videoconference system.

\subsection{The Network-Based or Flexible Education Model}

This is currently the most versatile model of distance learning delivery. It presents teaching and learning resources using a variety of technological applications. These include interactive multi-media online resources, databases and 
computer mediated communication using automated response systems. The flexibility built into this model allows students to study at their pace and convenience either on or off line

\section{Methodology}

The design used in this study is the cross-sectional survey. Data were collected from students participating in the DL programmes in the universities of Buea, Dschang Yaounde I and Douala. Data were collected using a close-ended Likert-scale questionnaire. The questionnaire items were categorized to facilitate the measurement and comparison of responses within indicators and within conceptual components.

\subsection{Participants}

The participants comprise students in the four campuses: Buea, Dschang, Douala and Yaounde I. The entire population of the students in each of the distance learning programmes was targeted because enrollments were not very large.

\subsection{Selection of Participants}

All students in all distance learning institutions of the study participated in the study because the size was small. The participants consisted of 60 students in Buea, 12 in Dschang, 9 in Douala and 16 in Yaounde I.

\subsection{Research Instrument}

The instrument used was a close-ended questionnaire made up of Likert-type scaled items. The questionnaire was developed from literature review and information from a pilot study. Demographic information was elicited in the first part and the second part constituted of seven items. Item one sought to elicit information on the model a distance learning programme is using. The remaining six items examined the effectiveness of use of the chosen model through the institution's provision of learner support.

\subsection{Reliability of the Instrument}

Reliability was calculated using Cronbach's coefficient alpha. This coefficient is used when items are not scored dichotomously. Alpha is the most appropriate method for computing reliability. Generally, an Alpha reliability coefficient above 0.5 is assumed to be satisfactory and the instrument considered reliable.

\subsection{Collection of Data}

The data for the first objective of the study was collected from a literature review. Data for the remaining two objectives was collected by email and face-to-face from participants. Data from the programme in Dschang was collected partly by emailing the student questionnaire to students who completed and returned it to me and I personally distributed some to students who came to 
submit their assignments and collated immediately after. The data in Douala was collected by email and that of Buea and Yaounde I was collected during face-toface tutorials.

\section{Findings}

The findings of this study are presented according to the research questions that guided the study. This research set out to find answers to the three questions of the study. That is, to identify (1) the distance learning models that are used in higher education institutions around the world, (2) identify and describe the models currently used in higher education in Cameroon, and (3) assess the effectiveness of the use of the selected model in each institution in Cameroon.

\subsection{Distance Learning Models Currently Used in Higher Education Institutions Worldwide}

A review of the literature reveals seven models of distance learning that are mostly used by institutions of higher learning worldwide to deliver distance learning. These models are: the Correspondence, Multi-media, Telelearning, Group distance learning, Autonomous learners' Technologically extended classroom teaching and the Network-based Models.

\subsection{Distance Learning Models Currently Used in Cameroon Higher Education}

The results of the study show that the Multi-media and the Telelearning models have been adopted by institutions of higher learning in Cameroon in the pursuit of their distance learning programmes.

The data reveal that the multi-media/study centre model is used by the distance learning programmes in the universities of Buea and Dschang. This is confirmed by the percentage usage of all the indicators of the model which varies from $71 \%$ to $100 \%$ usage in Buea and $67 \%$ to $100 \%$ in Dschang as presented on Table 1.

The information on the above table inidicates that the universities of Yaounde I and Douala have adopted the Telelearning (online learning) model for the implementation of their distance learning programmes. Table 2 shows that the University of YaoundéI and Douala are the only universities that make use of all the components of this model in the delivery of their programmes. The University of Yaounde I is using 7 of the 12 indicators at percentages ranging from 50\% to $100 \%$ while the University of Douala shows a percentage usage of between $50 \%$ to $100 \%$ on 8 of the 12 indicators. Email is used to facilitate submission of assignments by students and audio and video conferencing to facilitate communication between tutors and students and between students. Dedicated websites are used to provide preregistration information and to process applications from prospective students. However, the principal activities that this model is noted for facilitating, that is, computer mediated communication, audio and video 
Table 1. Multi-media model and support strategies.

\begin{tabular}{|c|c|c|c|c|c|c|}
\hline & & \multicolumn{4}{|c|}{ Institution } & \multirow{2}{*}{ Total } \\
\hline & & Buea & Dschang & Yaounde & Douala & \\
\hline \multirow{2}{*}{$\begin{array}{l}\text { Institution has a network } \\
\text { of study centers }\end{array}$} & $\mathrm{n}$ & 22 & 6 & 7 & 2 & 37 \\
\hline & $\%$ & $71.0 \%$ & $66.7 \%$ & $43.8 \%$ & $33.3 \%$ & $10.0 \%$ \\
\hline \multirow{2}{*}{$\begin{array}{l}\text { Support is provided at a study } \\
\text { center }\end{array}$} & $\mathrm{n}$ & 25 & 6 & 3 & 2 & 36 \\
\hline & $\%$ & $80.6 \%$ & $66.7 \%$ & $18.8 \%$ & $33.3 \%$ & $9.8 \%$ \\
\hline \multirow{2}{*}{$\begin{array}{l}\text { Receive course materials at } \\
\text { this study center }\end{array}$} & $\mathrm{n}$ & 26 & 8 & 5 & 3 & 42 \\
\hline & $\%$ & $83.9 \%$ & $88.9 \%$ & $31.3 \%$ & $50.0 \%$ & $11.4 \%$ \\
\hline \multirow{2}{*}{$\begin{array}{l}\text { Write tests and examinations } \\
\text { at this study center. }\end{array}$} & $\mathrm{n}$ & 31 & 8 & 3 & 3 & 45 \\
\hline & $\%$ & $100.0 \%$ & $88.9 \%$ & $18.8 \%$ & $50.0 \%$ & $12.2 \%$ \\
\hline \multirow{2}{*}{$\begin{array}{l}\text { Drop assignments at this study } \\
\text { center }\end{array}$} & $\mathrm{n}$ & 22 & 8 & 4 & 2 & 36 \\
\hline & $\%$ & $71.0 \%$ & $88.9 \%$ & $25.0 \%$ & $33.3 \%$ & $9.8 \%$ \\
\hline \multirow{2}{*}{$\begin{array}{l}\text { Pick up marked assignments } \\
\text { from this study center }\end{array}$} & $\mathrm{n}$ & 31 & 8 & 3 & 2 & 44 \\
\hline & $\%$ & $100.0 \%$ & $88.9 \%$ & $18.8 \%$ & $33.3 \%$ & $12.0 \%$ \\
\hline \multirow{2}{*}{$\begin{array}{l}\text { Receive information on grade in the } \\
\text { assignments at this study center }\end{array}$} & $\mathrm{n}$ & 31 & 9 & 5 & 2 & 47 \\
\hline & $\%$ & $100.0 \%$ & $100.0 \%$ & $31.3 \%$ & $33.3 \%$ & $12.8 \%$ \\
\hline \multirow{2}{*}{ Attend tutorials at this center } & $\mathrm{n}$ & 30 & 9 & 3 & 3 & 45 \\
\hline & $\%$ & $96.8 \%$ & $100.0 \%$ & $18.8 \%$ & $50.0 \%$ & $12.2 \%$ \\
\hline \multirow{3}{*}{ Write examinations at this center } & $\mathrm{n}$ & 30 & 1 & 3 & 2 & 36 \\
\hline & & & & & & \\
\hline & $\%$ & $96.8 \%$ & $11.1 \%$ & $18.8 \%$ & $33.3 \%$ & $9.8 \%$ \\
\hline
\end{tabular}

conferencing and dedicated database as well as the accompanying equipment are absent. This suggests that Learning or Course Management Systems may have been developed to provide a single platform for the integration of components and features for content delivery, communication, and evaluation

\subsection{The Effectiveness of the Use of Model by DL Institution}

The study examined the above question in terms of student's satisfaction with the provision of learner support. It assessed the ease with which students' access information; (1) before enrollment, (2) during the course of study (3) access to learning resources and equipment, (4) how they make use of opportunities for interaction, (5) benefit from motivational strategies (6) counseling services, (7) their ability to pay for learning materials required in the course of study and (8) ease of access to available learning equipment. The results are discussed in the following paragraphs. 
Table 2. Telelearning model and support strategies.

\begin{tabular}{|c|c|c|c|c|c|c|}
\hline \multirow{2}{*}{ Learner support Strategies } & & \multicolumn{4}{|c|}{ Name of institution } & \multirow{2}{*}{ Total } \\
\hline & & Buea & Dschang & Yaounde & Douala & \\
\hline \multirow{2}{*}{$\begin{array}{l}\text { Communicate with tutors and peers } \\
\text { through audio conferencing }\end{array}$} & $\mathrm{N}$ & 0 & 1 & 9 & 3 & 13 \\
\hline & $\%$ & $0.0 \%$ & $11.1 \%$ & $56.3 \%$ & $50.0 \%$ & $6.7 \%$ \\
\hline \multirow{2}{*}{$\begin{array}{l}\text { Communicate with tutors and peers } \\
\text { through Computer conferencing }\end{array}$} & $\mathrm{N}$ & 0 & 0 & 3 & 1 & 4 \\
\hline & $\%$ & $0.0 \%$ & $0.0 \%$ & $18.8 \%$ & $16.7 \%$ & $2.1 \%$ \\
\hline \multirow{2}{*}{$\begin{array}{l}\text { Communicate with tutors and peers } \\
\text { through Video conferencing }\end{array}$} & $\mathrm{N}$ & 1 & 5 & 12 & 6 & 24 \\
\hline & $\%$ & $3.2 \%$ & $55.6 \%$ & $75.0 \%$ & $100.0 \%$ & $12.4 \%$ \\
\hline \multirow{2}{*}{$\begin{array}{l}\text { Communicate with tutors and peers } \\
\text { through Email }\end{array}$} & $\mathrm{N}$ & 9 & 7 & 8 & 4 & 28 \\
\hline & $\%$ & $29.0 \%$ & $77.8 \%$ & $50.0 \%$ & $66.7 \%$ & $14.4 \%$ \\
\hline \multirow{2}{*}{$\begin{array}{l}\text { Communicate with tutors and peers } \\
\text { through Telephone }\end{array}$} & $\mathrm{N}$ & 25 & 0 & 12 & 3 & 40 \\
\hline & $\%$ & $80.6 \%$ & $0.0 \%$ & $75.0 \%$ & $50.0 \%$ & $20.6 \%$ \\
\hline \multirow{2}{*}{$\begin{array}{l}\text { Course materials are on a dedicated } \\
\text { website }\end{array}$} & $\mathrm{N}$ & 1 & 0 & 11 & 3 & 15 \\
\hline & $\%$ & $3.2 \%$ & $0.0 \%$ & $68.8 \%$ & $50.0 \%$ & $7.7 \%$ \\
\hline \multirow{2}{*}{$\begin{array}{l}\text { Access library resources on a dedicated } \\
\text { database }\end{array}$} & $\mathrm{N}$ & 2 & 0 & 3 & 0 & 5 \\
\hline & $\%$ & $6.5 \%$ & $0.0 \%$ & $18.8 \%$ & $0.0 \%$ & $2.6 \%$ \\
\hline \multirow{2}{*}{ Take examinations online } & $\mathrm{N}$ & 1 & 0 & 3 & 0 & 4 \\
\hline & $\%$ & $3.2 \%$ & $0.0 \%$ & $18.8 \%$ & $0.0 \%$ & $2.1 \%$ \\
\hline \multirow{2}{*}{$\begin{array}{l}\text { Access conferencing equipment in a } \\
\text { special study center }\end{array}$} & $\mathrm{N}$ & 2 & 0 & 4 & 2 & 8 \\
\hline & $\%$ & $6.5 \%$ & $0.0 \%$ & $25.0 \%$ & $33.3 \%$ & $4.1 \%$ \\
\hline \multirow{2}{*}{$\begin{array}{l}\text { Access conferencing equipment } \\
\text { at home }\end{array}$} & $\mathrm{N}$ & 2 & 0 & 16 & 6 & 24 \\
\hline & $\%$ & $6.5 \%$ & $0.0 \%$ & $100.0 \%$ & $100.0 \%$ & $12.4 \%$ \\
\hline \multirow{2}{*}{ Submit assignments online } & $\mathrm{N}$ & 0 & 0 & 14 & 3 & 17 \\
\hline & $\%$ & $0.0 \%$ & $0.0 \%$ & $87.5 \%$ & $50.0 \%$ & $8.8 \%$ \\
\hline \multirow{3}{*}{ Receive assignments by email } & $\mathrm{N}$ & 2 & 2 & 5 & 3 & 12 \\
\hline & & & & & & \\
\hline & $\%$ & $6.5 \%$ & $22.2 \%$ & $31.3 \%$ & $50.0 \%$ & $6.2 \%$ \\
\hline
\end{tabular}

\subsection{Satisfaction with the Provision of Information before Enrolment (Table 3)}

There is a significant variation among the institutions regarding student's satisfaction with information received before enrollment. Students of the institution in Dschang reported the highest level of satisfaction (76.5\%), followed by Yaounde I (70.7\%), Buea (68.5\%) and Douala (59.1\%) (Figure 1). 
Table 3. Student satisfaction with the provision of pre-registration information.

\begin{tabular}{|c|c|c|c|c|c|c|}
\hline \multirow{2}{*}{ Information on } & & \multicolumn{4}{|c|}{ Name of institution } & \multirow{2}{*}{ Total } \\
\hline & & Buea & Dschang & Yaounde & Douala & \\
\hline \multirow{3}{*}{ The enrolment process } & $\mathrm{n}$ & 30 & 9 & 15 & 6 & 60 \\
\hline & & & & & & \\
\hline & $\%$ & $96.8 \%$ & $100.0 \%$ & $93.8 \%$ & $100.0 \%$ & $13.0 \%$ \\
\hline \multirow{3}{*}{ Structure of the program } & $\mathrm{n}$ & 25 & 8 & 12 & 4 & 49 \\
\hline & & & & & & \\
\hline & $\%$ & $80.6 \%$ & $88.9 \%$ & $75.0 \%$ & $66.7 \%$ & $10.6 \%$ \\
\hline \multirow{3}{*}{ The objective of each course } & $\mathrm{n}$ & 30 & 7 & 11 & 4 & 52 \\
\hline & & & & & & \\
\hline & $\%$ & $96.8 \%$ & $77.8 \%$ & $68.8 \%$ & $66.7 \%$ & $11.2 \%$ \\
\hline \multirow{3}{*}{ The course outlines } & $\mathrm{n}$ & 28 & 6 & 12 & 4 & 50 \\
\hline & & & & & & \\
\hline & $\%$ & $90.3 \%$ & $66.7 \%$ & $75.0 \%$ & $66.7 \%$ & $10.8 \%$ \\
\hline \multirow{3}{*}{ The target audience for each course } & $\mathrm{n}$ & 22 & 8 & 8 & 4 & 42 \\
\hline & & & & & & \\
\hline & $\%$ & $71.0 \%$ & $88.9 \%$ & $50.0 \%$ & $66.7 \%$ & $9.1 \%$ \\
\hline \multirow{2}{*}{$\begin{array}{l}\text { The requirements for each course } \\
\text { (e.g. study hours, attendances } \\
\text { at tutorial or summer schools) }\end{array}$} & $\mathrm{n}$ & 16 & 8 & 10 & 4 & 38 \\
\hline & $\%$ & $51.6 \%$ & $88.9 \%$ & $62.5 \%$ & $66.7 \%$ & $8.2 \%$ \\
\hline \multirow{2}{*}{$\begin{array}{l}\text { The start and the end dates of } \\
\text { the Course }\end{array}$} & $\mathrm{n}$ & 15 & 6 & 11 & 2 & 34 \\
\hline & $\%$ & $48.4 \%$ & $66.7 \%$ & $68.8 \%$ & $33.3 \%$ & $7.3 \%$ \\
\hline \multirow{3}{*}{ Materials provided with the course } & $\mathrm{n}$ & 23 & 7 & 10 & 2 & 42 \\
\hline & & & & & & \\
\hline & $\%$ & $74.2 \%$ & $77.8 \%$ & $62.5 \%$ & $33.3 \%$ & $9.1 \%$ \\
\hline \multirow{3}{*}{ Cost of the course } & $\mathrm{n}$ & 6 & 2 & 10 & 1 & 19 \\
\hline & & & & & & \\
\hline & $\%$ & $19.4 \%$ & $22.2 \%$ & $62.5 \%$ & $16.7 \%$ & $4.1 \%$ \\
\hline \multirow{2}{*}{$\begin{array}{l}\text { Technology resources of students for } \\
\text { the course (e.g. telephone, computer, } \\
\text { internet, and text books.) }\end{array}$} & $\mathrm{n}$ & 9 & 7 & 11 & 4 & 31 \\
\hline & $\%$ & $29.0 \%$ & $77.8 \%$ & $68.8 \%$ & $66.7 \%$ & $6.7 \%$ \\
\hline \multirow{2}{*}{$\begin{array}{l}\text { Qualification awarded on } \\
\text { completion of course. }\end{array}$} & $\mathrm{n}$ & 27 & 7 & 8 & 4 & 46 \\
\hline & $\%$ & $87.1 \%$ & $77.8 \%$ & $50.0 \%$ & $66.7 \%$ & $9.9 \%$ \\
\hline \multirow{3}{*}{ AGREGATED SCORE (MRS) } & $\mathbf{n}$ & 231 & 75 & 118 & 39 & 463 \\
\hline & & & & & & \\
\hline & $\%$ & $68.5 \%$ & $76.5 \%$ & $70.7 \%$ & $59.1 \%$ & $69.3 \%$ \\
\hline $\mathrm{N}$ (Total number of responses) & & 337 & 98 & 167 & 66 & $668(100.0 \%)$ \\
\hline
\end{tabular}

$\chi^{2}$-test: $\chi^{2}=6.04 ; \mathrm{df}=3 ; \mathrm{P}=0.109$. 


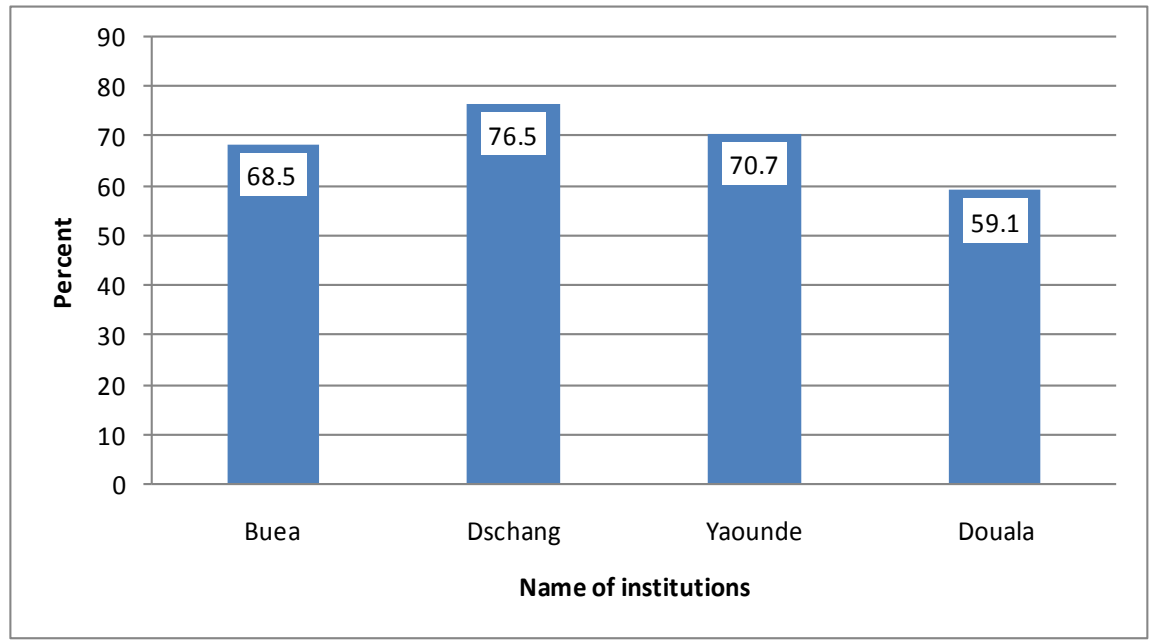

Figure 1. Satisfaction with the provision of information needed before enrolment.

More than two thirds (68.72\%) of the students are generally satisfied with the information provided before enrollment into the programmes. Students are most satisfied (76.5\%) in Dschang and least satisfied in Douala (59.1\%).

\subsection{Provision of Information during the Course of Study (Table 4)}

There is a significant variation among the institutions. The programmes in Yaounde I and Douala show a steady dissatisfaction with: getting help with course problems ( $50 \%$ vs $50 \%$ ), getting help with administrative problems (50\% vs $33 \%$ ), information on contact period ( $50 \%$ vs $33 \%$ ), assessment modalities (56\% vs $33 \%)$, and task per semester in Douala (17\%). Dschang is lowest (56\%) on student tutor information and Buea (45\%) on getting help with administrative problems. Therefore, the institution in Dschang is most effective in providing on the course information (81\%), followed by Buea (74.2\%) and Yaounde I (60.5\%) (Figure 2).

About two thirds (64.0\%) of the students are satisfied with the provision of on course information. Highest $81.1 \%$ is Dschang and the least $40.0 \%$ is Douala.

\subsection{Ease of Access to Available Learning Resources}

Table 5 that follows shows student satisfaction with access to learning with respect to selected resources.

There is a significant variation in access to learning resources among the institutions. Access to learning resources provided by all the institutions is generally unsatisfactory. However, access to learning resources is more effective in Dschang and Buea were students reported satisfaction on 5 of the 8 indicators than in Yaounde I ( 4 indicators) and Douala ( 2 indicators) (Figure 3 ).

Slightly above half of the students (60\%) are satisfied with access to learning resources. Students in Dschang (61\%) reported the highest level of satisfactionagainst (40\%) in Douala. 
Table 4. Student satisfaction with information provided during the course of study.

\begin{tabular}{|c|c|c|c|c|c|c|}
\hline \multirow{2}{*}{ Study information on } & & \multicolumn{4}{|c|}{ Name of institution } & \multirow{2}{*}{ Total } \\
\hline & & Buea & Dschang & Yaounde & Douala & \\
\hline \multirow{2}{*}{$\begin{array}{l}\text { How to get help with course } \\
\text { problems }\end{array}$} & $\mathrm{n}$ & 24 & 8 & 8 & 3 & 43 \\
\hline & $\%$ & $77.4 \%$ & $88.9 \%$ & $50.0 \%$ & $50.0 \%$ & $17.4 \%$ \\
\hline \multirow{2}{*}{$\begin{array}{l}\text { How to get help with } \\
\text { administrative problems }\end{array}$} & $\mathrm{n}$ & 14 & 9 & 8 & 2 & 33 \\
\hline & $\%$ & $45.2 \%$ & $100.0 \%$ & $50.0 \%$ & $33.3 \%$ & $13.4 \%$ \\
\hline \multirow{3}{*}{ The task for each semester } & $\mathrm{n}$ & 28 & 7 & 10 & 1 & 46 \\
\hline & & & & & & \\
\hline & $\%$ & $90.3 \%$ & $77.8 \%$ & $62.5 \%$ & $16.7 \%$ & $18.6 \%$ \\
\hline \multirow{2}{*}{ Information on student tutor } & $\mathrm{n}$ & 22 & 5 & 9 & 4 & 40 \\
\hline & $\%$ & $71.0 \%$ & $55.6 \%$ & $56.3 \%$ & $66.7 \%$ & $16.2 \% \%$ \\
\hline \multirow{2}{*}{$\begin{array}{l}\text { Detailed information on the } \\
\text { contact Period }\end{array}$} & $\mathrm{n}$ & 21 & 7 & 8 & 2 & 38 \\
\hline & $\%$ & $67.7 \%$ & $77.8 \%$ & $50.0 \%$ & $33.3 \%$ & $15.4 \%$ \\
\hline \multirow{3}{*}{ How students will be assessed } & $\mathrm{n}$ & 29 & 7 & 9 & 2 & 47 \\
\hline & & & & & & \\
\hline & $\%$ & $93.5 \%$ & $77.8 \%$ & $56.3 \%$ & $33.3 \%$ & $19.0 \%$ \\
\hline \multirow{3}{*}{ AGREGATED SCORE (MRS) } & $\mathrm{n}$ & 138 & 43 & 52 & 14 & 247 \\
\hline & & & & & & \\
\hline & $\%$ & $74.2 \%$ & $81.1 \%$ & $60.5 \%$ & $40.0 \%$ & $68.6 \%$ \\
\hline $\mathbf{N}$ (Total number of responses) & & 186 & 53 & 86 & 35 & $360(100.0 \%)$ \\
\hline
\end{tabular}

$\chi^{2}$-test: $\chi^{2}=42.41 ; \mathrm{df}=3 ; \mathrm{P}<0.001$.

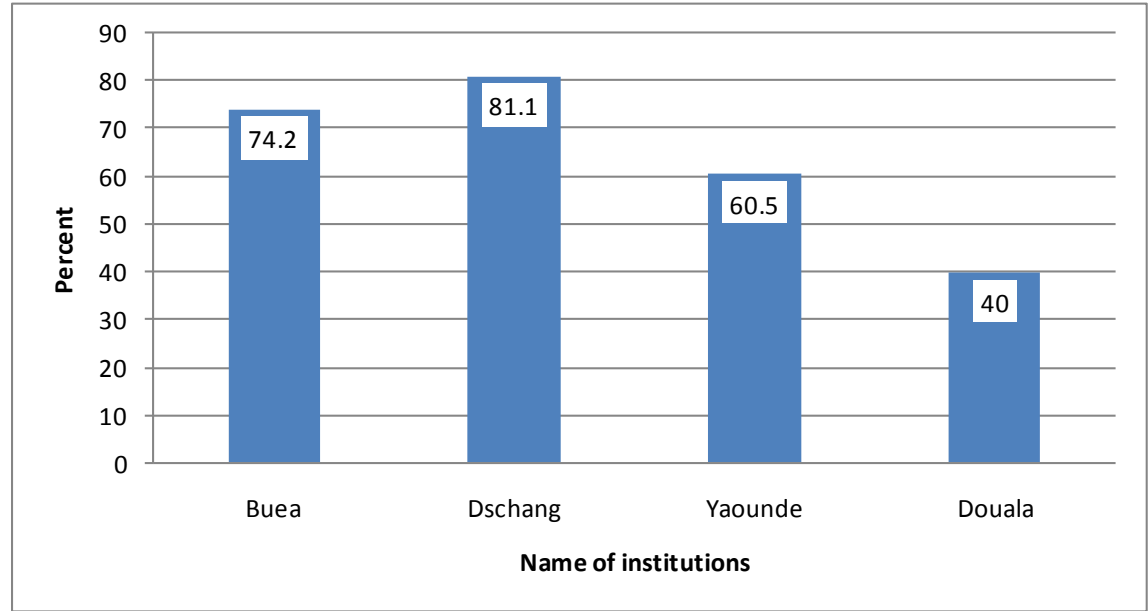

Figure 2. Satisfaction with the provision of information during the course of study. 
Table 5. Student satisfaction with access to learning resources available in the course.

\begin{tabular}{|c|c|c|c|c|c|c|}
\hline \multirow{2}{*}{ Learning resources } & & \multicolumn{4}{|c|}{ Institution } & \multirow{2}{*}{ Total } \\
\hline & & Buea & Dschang & Yaounde & Douala & \\
\hline \multirow{3}{*}{ Course materials } & $\mathrm{n}$ & 21 & 8 & 11 & 2 & 42 \\
\hline & & & & & & \\
\hline & $\%$ & $67.7 \%$ & $88.9 \%$ & $68.8 \%$ & $33.3 \%$ & $11.1 \%$ \\
\hline \multirow[b]{2}{*}{ Course guides } & $\mathrm{n}$ & 20 & 5 & 9 & 2 & 36 \\
\hline & $\%$ & $64.5 \%$ & $55.6 \%$ & $56.3 \%$ & $33.3 \%$ & $9.5 \%$ \\
\hline \multirow{2}{*}{ Library resources } & $\mathrm{n}$ & 11 & 2 & 11 & 3 & 27 \\
\hline & $\%$ & $35.5 \%$ & $22.2 \%$ & $68.8 \%$ & $50.0 \%$ & $7.1 \%$ \\
\hline \multirow{2}{*}{ Internet recourses } & $\mathrm{n}$ & 15 & 2 & 8 & 4 & 29 \\
\hline & $\%$ & $48.4 \%$ & $22.2 \%$ & $50.0 \%$ & $66.7 \%$ & $7.7 \%$ \\
\hline \multirow{2}{*}{ Study center facilities } & $\mathrm{n}$ & 18 & 3 & 8 & 0 & 29 \\
\hline & $\%$ & $58.1 \%$ & $33.3 \%$ & $50.0 \%$ & $0.0 \%$ & $7.7 \%$ \\
\hline \multirow[b]{2}{*}{ Tutors } & $\mathrm{n}$ & 23 & 7 & 8 & 2 & 40 \\
\hline & $\%$ & $74.2 \%$ & $77.8 \%$ & $50.0 \%$ & $33.3 \%$ & $10.6 \%$ \\
\hline \multirow{2}{*}{ Course instructors } & $\mathrm{n}$ & 24 & 8 & 7 & 2 & 41 \\
\hline & $\%$ & $77.4 \%$ & $88.9 \%$ & $43.8 \%$ & $33.3 \%$ & $10.8 \%$ \\
\hline \multirow{2}{*}{ Institutional administration } & $\mathrm{n}$ & 14 & 8 & 9 & 4 & 35 \\
\hline & $\%$ & $45.2 \%$ & $88.9 \%$ & $56.3 \%$ & $66.7 \%$ & $9.3 \%$ \\
\hline \multirow{2}{*}{ AGREGATED SCORE (MRS) } & $\mathbf{N}$ & 146 & 43 & 71 & 19 & 279 \\
\hline & $\%$ & $59.8 \%$ & $60.6 \%$ & $59.2 \%$ & $39.6 \%$ & $57.1 \%$ \\
\hline $\mathrm{N}$ (Total number of responses) & & 244 & 71 & 120 & 48 & $483(100.0 \%)$ \\
\hline
\end{tabular}

$\chi^{2}$-test: $\chi^{2}=7.26 ; \mathrm{df}=3 ; \mathrm{P}=0.064$

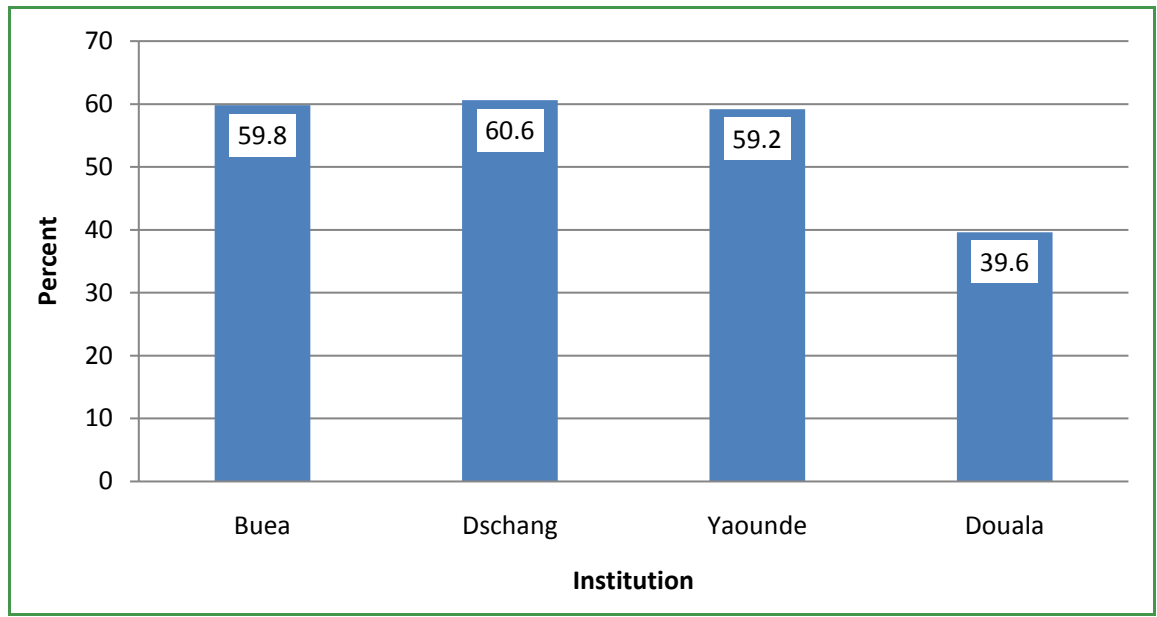

Figure 3. Satisfaction with access to learning resources available to students in the course. 


\subsection{Interaction in the Programmes}

Table 6 indicates the level of student satisfaction in relation to selected modes of interaction.

There is a significant variation in the satisfaction levels with interaction strategies among the institutions. In general the level of interaction in the programmes is very low (below 48\%). However, interaction is most effective in the programme in Buea where students reported satisfaction on 5 of the 7 indicators. Therefore, interaction is better in institutions using the multi-media model than in those using the on-line learning model (Figure 4).

The general level $(43.1 \%)$ of satisfaction with interaction is below average. However, student satisfaction is least $(38.1 \%)$ in Doualaand highest $(48.4 \%)$ in Buea. Therefore, the majority of students in all institutions reported dissatisfaction with interaction in all the universities $\left(\chi^{2}\right.$-test: $\left.\mathrm{P}=0.479\right)$. Interaction which is a key component of distance education remains a great challenge in distance learning institutions in Cameroon (Table 7).

Table 6. Student satisfaction with interaction in the course.

\begin{tabular}{|c|c|c|c|c|c|c|}
\hline \multirow{2}{*}{ Interaction Strategies } & & \multicolumn{4}{|c|}{ Institution } & \multirow{2}{*}{ Total } \\
\hline & & Buea & Dschang & Yaounde & Douala & \\
\hline \multirow{3}{*}{ Face to face tutorials } & $\mathrm{N}$ & 29 & 6 & 6 & 2 & 43 \\
\hline & & & & & & \\
\hline & $\%$ & $93.5 \%$ & $66.7 \%$ & $37.5 \%$ & $33.3 \%$ & $22.9 \%$ \\
\hline \multirow{3}{*}{ Feedback on assignments } & $\mathrm{N}$ & 26 & 7 & 6 & 2 & 41 \\
\hline & & & & & & \\
\hline & $\%$ & $83.9 \%$ & $77.8 \%$ & $37.5 \%$ & $33.3 \%$ & $21.8 \%$ \\
\hline \multirow{2}{*}{ Counseling } & $\mathrm{N}$ & 26 & 0 & 4 & 0 & 30 \\
\hline & $\%$ & $83.9 \%$ & $0.0 \%$ & $25.0 \%$ & $0.0 \%$ & $16.0 \%$ \\
\hline \multirow[b]{2}{*}{ Audio conferencing } & $\mathrm{N}$ & 2 & 0 & 3 & 1 & 6 \\
\hline & $\%$ & $6.5 \%$ & $0.0 \%$ & $18.8 \%$ & $16.7 \%$ & $3.2 \%$ \\
\hline \multirow{2}{*}{ Video conferencing } & $\mathrm{N}$ & 0 & 0 & 8 & 2 & 10 \\
\hline & $\%$ & $0.0 \%$ & $0.0 \%$ & $50.0 \%$ & $33.3 \%$ & $5.3 \%$ \\
\hline \multirow{3}{*}{ Computer conferencing } & $\mathrm{N}$ & 0 & 4 & 8 & 3 & 15 \\
\hline & & & & & & \\
\hline & $\%$ & $0.0 \%$ & $44.4 \%$ & $50.0 \%$ & $50.0 \%$ & $7.9 \%$ \\
\hline $\begin{array}{l}\text { Your ability to contact the } \\
\text { appropriate official to solve }\end{array}$ & $\mathrm{N}$ & 20 & 9 & 8 & 6 & 43 \\
\hline different learning difficulties & $\%$ & $64.5 \%$ & $100.0 \%$ & $50.0 \%$ & $100.0 \%$ & $22.9 \%$ \\
\hline \multirow{3}{*}{ AGREGATED SCORE (MRS) } & $\mathbf{N}$ & 103 & 26 & 43 & 16 & 188 \\
\hline & & & & & & \\
\hline & $\%$ & $48.4 \%$ & $44.8 \%$ & $41.0 \%$ & $38.1 \%$ & $45.0 \%$ \\
\hline $\mathbf{N}$ (Total number of responses) & & 213 & 58 & 105 & 42 & $418(100.0 \%)$ \\
\hline
\end{tabular}




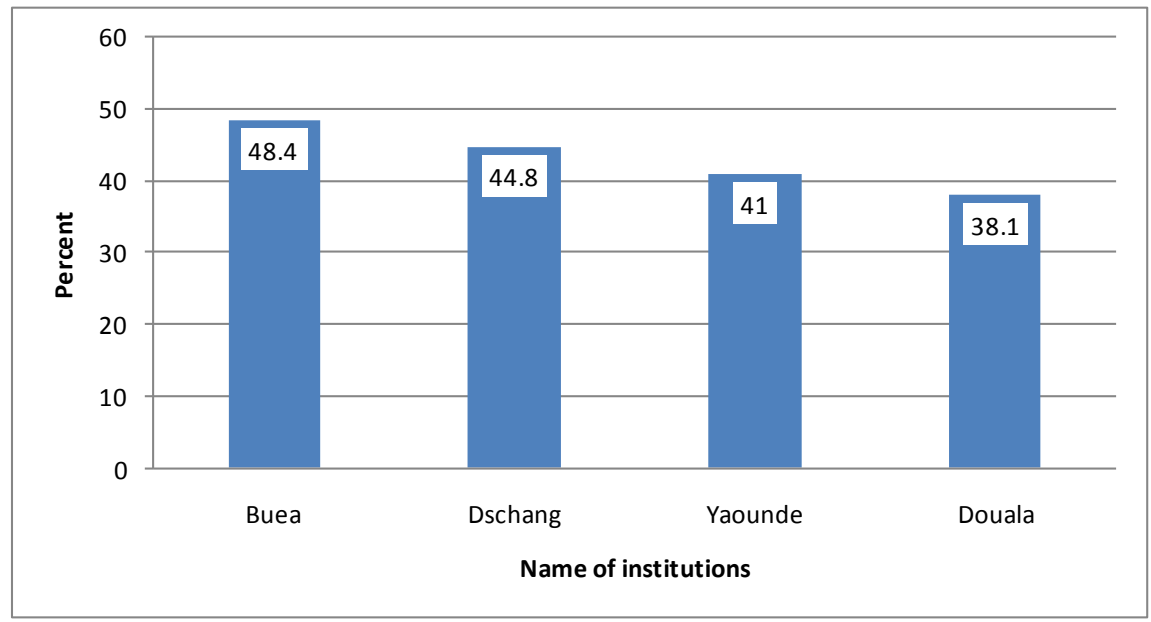

Figure 4. Satisfaction with interaction in the course.

Table 7. Extent to which learning strategies help student to stay on the programme.

\begin{tabular}{|c|c|c|c|c|c|c|}
\hline \multirow{2}{*}{ Learning strategies } & & \multicolumn{4}{|c|}{ Institution } & \multirow{2}{*}{ Total } \\
\hline & & Buea & Dschang & Yaounde & Douala & \\
\hline \multirow{2}{*}{ Time management } & $\mathrm{n}$ & 26 & 7 & 8 & 2 & 43 \\
\hline & $\%$ & $83.9 \%$ & $77.8 \%$ & $50.0 \%$ & $33.3 \%$ & $8.2 \%$ \\
\hline \multirow{2}{*}{$\begin{array}{l}\text { ability to understanding } \\
\text { difficult material }\end{array}$} & $\mathrm{n}$ & 25 & 8 & 10 & 3 & 46 \\
\hline & $\%$ & $80.6 \%$ & $88.9 \%$ & $62.5 \%$ & $50.0 \%$ & $8.8 \%$ \\
\hline \multirow{2}{*}{$\begin{array}{l}\text { ability to prepare and submit } \\
\text { assignments regularly }\end{array}$} & $\mathrm{n}$ & 28 & 9 & 6 & 4 & 47 \\
\hline & $\%$ & $90.3 \%$ & $100.0 \%$ & $37.5 \%$ & $66.7 \%$ & $9.0 \%$ \\
\hline \multirow{2}{*}{$\begin{array}{l}\text { performance in the } \\
\text { assignments }\end{array}$} & $\mathrm{n}$ & 30 & 8 & 9 & 2 & 49 \\
\hline & $\%$ & $96.8 \%$ & $88.9 \%$ & $56.3 \%$ & $33.3 \%$ & $9.4 \%$ \\
\hline \multirow{2}{*}{ Attitude of tutors } & $\mathrm{n}$ & 29 & 8 & 13 & 3 & 53 \\
\hline & $\%$ & $93.5 \%$ & $88.9 \%$ & $81.3 \%$ & $50.0 \%$ & $10.1 \%$ \\
\hline \multirow{2}{*}{ Reputation of the institution } & $\mathrm{n}$ & 29 & 9 & 12 & 5 & 55 \\
\hline & $\%$ & $93.5 \%$ & $100.0 \%$ & $75.0 \%$ & $83.3 \%$ & $10.5 \%$ \\
\hline \multirow{2}{*}{ Success of the other learners } & $\mathrm{n}$ & 29 & 5 & 10 & 3 & 47 \\
\hline & $\%$ & $93.5 \%$ & $55.6 \%$ & $62.5 \%$ & $50.0 \%$ & $9.0 \%$ \\
\hline \multirow{2}{*}{$\begin{array}{l}\text { Ability to study the course } \\
\text { material independently }\end{array}$} & $\mathrm{n}$ & 23 & 7 & 9 & 3 & 42 \\
\hline & $\%$ & $74.2 \%$ & $77.8 \%$ & $56.3 \%$ & $50.0 \%$ & $8.1 \%$ \\
\hline \multirow{2}{*}{$\begin{array}{l}\text { Mastery of study skills as a } \\
\text { distant learner }\end{array}$} & $\mathrm{n}$ & 25 & 9 & 10 & 2 & 46 \\
\hline & $\%$ & $80.6 \%$ & $100.0 \%$ & $62.5 \%$ & $33.3 \%$ & $8.8 \%$ \\
\hline \multirow{2}{*}{$\begin{array}{l}\text { The assessment method } \\
\text { used in the course }\end{array}$} & $\mathrm{n}$ & 27 & 8 & 3 & 3 & 41 \\
\hline & $\%$ & $87.1 \%$ & $88.9 \%$ & $18.8 \%$ & $50.0 \%$ & $7.8 \%$ \\
\hline \multirow{2}{*}{ Tutors comment on assignment } & $\mathrm{n}$ & 29 & 9 & 14 & 2 & 54 \\
\hline & $\%$ & $93.5 \%$ & $100.0 \%$ & $87.5 \%$ & $33.3 \%$ & $10.3 \%$ \\
\hline \multirow{2}{*}{ AGREGATED SCORE (MRS) } & $\mathrm{n}$ & 300 & 87 & 104 & 32 & 523 \\
\hline & $\%$ & $90.1 \%$ & $88.8 \%$ & $63.0 \%$ & $48.5 \%$ & $79.0 \%$ \\
\hline $\mathrm{N}$ (Total number of responses) & & 333 & 98 & 165 & 66 & $662(100.0 \%)$ \\
\hline
\end{tabular}

$\chi^{2}$-test: $\chi^{2}=92.75 ; \mathrm{df}=3 ; \mathrm{P}<0.001$. 
There is a significant variation among the institutions regarding the use of strategies that enable students to stay on the programme. Students reported satisfaction with all the strategies in Buea and Dschang, on 6 of the 11 indicators in Yaounde I and on 2 indicators in Douala. Therefore, institutions using the multi-media model of distance education are more effective in using strategies that enable students to stay on their programmes than those using the online-learning model (Figure 5).

Over two thirds (72.6\%) of the students are satisfied with the extent to which learning strategies assist them remain in the programmes. Satisfaction levels are highest (90\%) in Bueaand least (49\%) in Douala. Variation by institution is statistically significant.

\subsection{Counseling Services}

Table 8 shows the level of student satisfaction with learning in relation to the influence of selected counseling activities.

There is a very significant variation among the institutions concerning the usefulness of counseling services in solving learning related problems. Satisfaction levels in the institutions in Dschang and Buea are consistently higher than those of Yaounde I and Douala. Students reported that counseling was most useful in Dschang by expressing satisfaction on all 8 indicators. This is followed by Yaounde I with student satisfaction on 7 and Buea with satisfaction on 6 of the 8 indicators. Consequently, counseling is more effectively used in institutions using the study centre model than in those using the telelearning model of distance education (Figure 6).

(65\%) of all the students express satisfaction with the use of counselling services to solve problems affecting their learning ranging from $78 \%$ in Dschang to $71 \%$ in Buea. Students reported dissatisfaction in Douala (42\%) (Table 9).

This may also be related to the nature of their programmes as they are mediated more by print materials. The variation among the institutions relating to

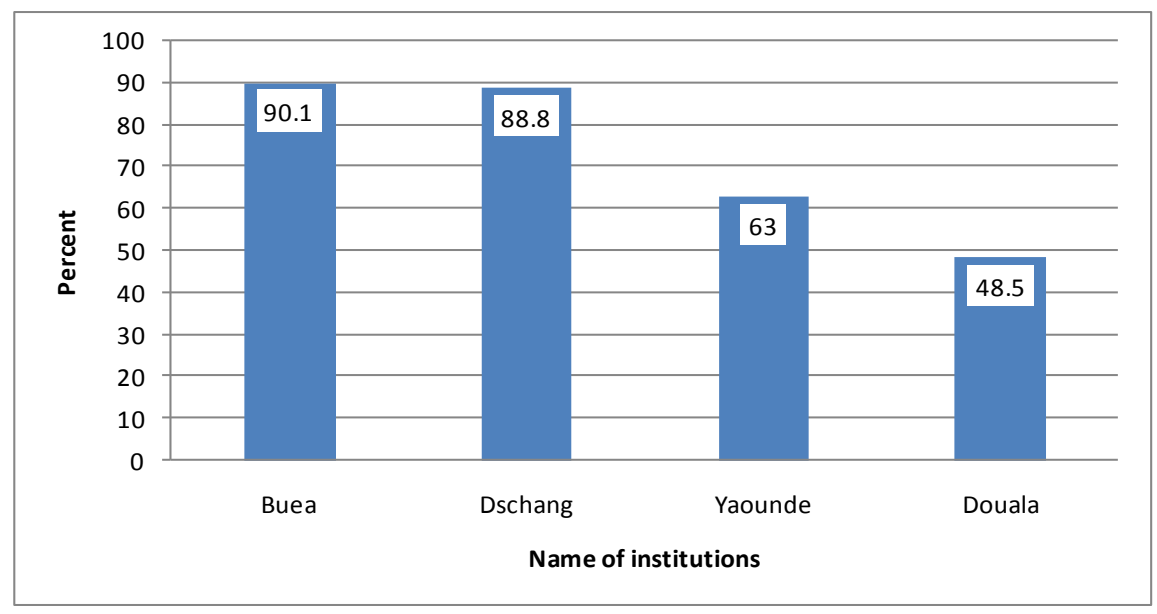

Figure 5. Satisfaction with extent to which learning strategies help retain students in the programme. 
Table 8. Usefulness of counseling in solving student's learning problems.

\begin{tabular}{|c|c|c|c|c|c|c|}
\hline \multirow{2}{*}{ Counseling activities } & & \multicolumn{4}{|c|}{ Institution } & \multirow{2}{*}{ Total } \\
\hline & & Buea & Dschang & Yaounde & Douala & \\
\hline \multirow{2}{*}{ Choosing the sequence of courses } & $\mathrm{n}$ & 24 & 6 & 12 & 4 & 46 \\
\hline & $\%$ & $77.4 \%$ & $66.7 \%$ & $75.0 \%$ & $66.7 \%$ & $14.1 \%$ \\
\hline \multirow{2}{*}{ Development of study skills } & $\mathrm{n}$ & 25 & 7 & 11 & 4 & 47 \\
\hline & $\%$ & $80.6 \%$ & $77.8 \%$ & $68.8 \%$ & $66.7 \%$ & $14.4 \%$ \\
\hline \multirow{2}{*}{ Studying part-time } & $\mathrm{n}$ & 23 & 8 & 11 & 4 & 46 \\
\hline & $\%$ & $74.2 \%$ & $88.9 \%$ & $68.8 \%$ & $66.7 \%$ & $14.1 \%$ \\
\hline \multirow{2}{*}{ Combining work with study } & $\mathrm{n}$ & 21 & 7 & 8 & 0 & 36 \\
\hline & $\%$ & $67.7 \%$ & $77.8 \%$ & $50.0 \%$ & $0.0 \%$ & $11.0 \%$ \\
\hline \multirow{2}{*}{$\begin{array}{l}\text { Personal problems } \\
\text { (e.g. family life and finances) }\end{array}$} & $\mathrm{n}$ & 15 & 7 & 10 & 1 & 33 \\
\hline & $\%$ & $48.4 \%$ & $77.8 \%$ & $62.5 \%$ & $16.7 \%$ & $10.1 \%$ \\
\hline \multirow{2}{*}{$\begin{array}{l}\text { How the distant learning } \\
\text { system works }\end{array}$} & $\mathrm{n}$ & 25 & 8 & 11 & 2 & 46 \\
\hline & $\%$ & $80.6 \%$ & $88.9 \%$ & $68.8 \%$ & $33.3 \%$ & $14.1 \%$ \\
\hline \multirow{2}{*}{ Time management } & $\mathrm{n}$ & 22 & 7 & 10 & 3 & 42 \\
\hline & $\%$ & $71.0 \%$ & $77.8 \%$ & $62.5 \%$ & $50.0 \%$ & $12.9 \%$ \\
\hline \multirow{2}{*}{ Employment opportunities } & $\mathrm{n}$ & 13 & 6 & 9 & 2 & 30 \\
\hline & $\%$ & $41.9 \%$ & $66.7 \%$ & $56.3 \%$ & $33.3 \%$ & $9.3 \%$ \\
\hline \multirow{2}{*}{ AGREGATED SCORE (MRS) } & $\mathrm{n}$ & 168 & 56 & 82 & 20 & 326 \\
\hline & $\%$ & $70.6 \%$ & $77.8 \%$ & $71.3 \%$ & $41.7 \%$ & $68.9 \%$ \\
\hline $\mathrm{N}$ (Total number of responses) & & 238 & 72 & 115 & 48 & $473(100.0 \%)$ \\
\hline
\end{tabular}

$\chi^{2}$-test: $\chi^{2}=19.90 ; \mathrm{df}=3 ; \mathrm{P}<0.001$.

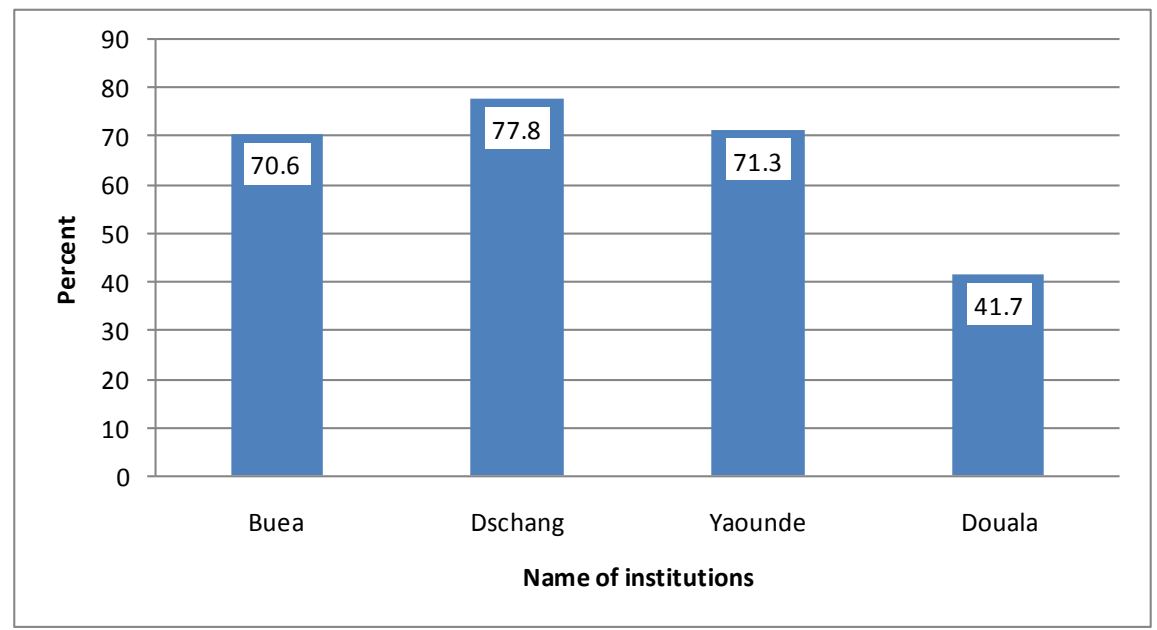

Figure 6. Satisfaction with usefulness of counseling in solving problems 29. affecting studies. 
Table 9. Ease with which student afford needed learning equipment.

\begin{tabular}{|c|c|c|c|c|c|c|}
\hline \multirow{2}{*}{ Learning equipment } & & \multicolumn{4}{|c|}{ Institution } & \multirow{2}{*}{ Total } \\
\hline & & Buea & Dschang & Yaounde & Douala & \\
\hline \multirow{3}{*}{ A computer } & $\mathrm{N}$ & 10 & 7 & 8 & 2 & 27 \\
\hline & & & & & & \\
\hline & $\%$ & $32.3 \%$ & $77.8 \%$ & $50.0 \%$ & $33.3 \%$ & $24.1 \%$ \\
\hline \multirow{2}{*}{ Pay for internet connection } & $\mathrm{N}$ & 8 & 1 & 8 & 2 & 19 \\
\hline & $\%$ & $25.8 \%$ & $11.1 \%$ & $50.0 \%$ & $33.3 \%$ & $16.9 \%$ \\
\hline \multirow{2}{*}{ Audio player } & $\mathrm{N}$ & 4 & 1 & 7 & 2 & 14 \\
\hline & $\%$ & $12.9 \%$ & $11.1 \%$ & $43.8 \%$ & $33.3 \%$ & $12.5 \%$ \\
\hline \multirow[b]{2}{*}{ Audio cassettes } & $\mathrm{N}$ & 7 & 1 & 8 & 2 & 18 \\
\hline & $\%$ & $22.6 \%$ & $11.1 \%$ & $50.0 \%$ & $33.3 \%$ & $16.1 \%$ \\
\hline \multirow{2}{*}{ CD/DVD ROMs } & $\mathrm{N}$ & 7 & 1 & 6 & 2 & 16 \\
\hline & $\%$ & $22.6 \%$ & $11.1 \%$ & $37.5 \%$ & $33.3 \%$ & $14.3 \%$ \\
\hline \multirow[b]{2}{*}{ CD/DVD player } & $\mathrm{N}$ & 3 & 4 & 8 & 3 & 18 \\
\hline & $\%$ & $9.7 \%$ & $44.4 \%$ & $50.0 \%$ & $50.0 \%$ & $16.1 \%$ \\
\hline \multirow{2}{*}{ AGREGATED SCORE (MRS) } & $\mathrm{N}$ & 39 & 15 & 45 & 13 & 112 \\
\hline & $\%$ & $22.0 \%$ & $30.0 \%$ & $53.6 \%$ & $36.1 \%$ & $32.3 \%$ \\
\hline $\mathrm{N}$ (Total number of responses) & & 177 & 50 & 84 & 36 & $347(100.0 \%)$ \\
\hline
\end{tabular}

the ease with which students afford learning equipment of the programmes is very significant. Generally students are unable to pay for the learning equipment associate with the adopted models. This may be due to the low salary situation nationwide. It may also indicate that the cost of the programmes is high compared to the learners' financial resources. Generally students have serious difficulties paying for internet connection, CD/DVD ROMS and a computer. Students in the programmes in Buea and Dschang experience greater difficulties paying for equipment but and face-to-face tutorials (Figure 7).

The average degrees of ease (35\%) with which all students afford learning equipment is very low possibly due to the low salary situation. The situation is more acute for Students (22\%) in Buea and (30\%) Dschang (Table 10).

There is a very significant variation among the institutions regarding the ease with which students' access learning equipment provided by the institution. There is a minimal use of ICT equipment reported in all the programmes. With the exception of computers and internet connectivity all other equipment has not been provided in Buea and Dschang. This implies that their programmes are heavily dependent on print materials. In Yaounde I and Douala where the programmes are supposed to be mediated by technology the situation is no better. 


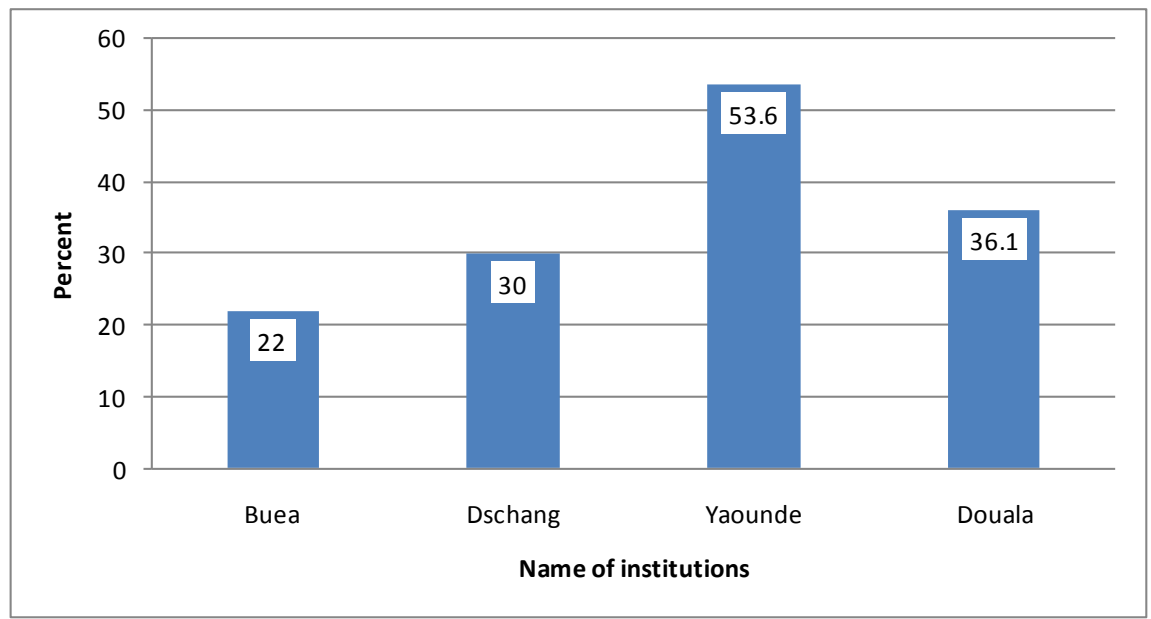

Figure 7. Ease with which student afford needed learning equipment.

Table 10. Ease of access to learning equipment at the study center.

\begin{tabular}{|c|c|c|c|c|c|c|}
\hline \multirow{2}{*}{ Learning equipment's } & & \multicolumn{4}{|c|}{ Institution } & \multirow{2}{*}{ Total } \\
\hline & & Buea & Dschang & Yaounde & Douala & \\
\hline \multirow{2}{*}{ A computer } & $\mathrm{n}$ & 10 & 5 & 9 & 3 & 27 \\
\hline & $\%$ & $32.3 \%$ & $55.6 \%$ & $56.3 \%$ & $50.0 \%$ & $28.4 \%$ \\
\hline \multirow{2}{*}{ Internet connection } & $\mathrm{n}$ & 8 & 1 & 6 & 1 & 16 \\
\hline & $\%$ & $25.8 \%$ & $11.1 \%$ & $37.5 \%$ & $16.7 \%$ & $16.9 \%$ \\
\hline \multirow{2}{*}{ Audio player } & $\mathrm{n}$ & 1 & 0 & 5 & 0 & 6 \\
\hline & $\%$ & $3.2 \%$ & $0.0 \%$ & $31.3 \%$ & $0.0 \%$ & $6.3 \%$ \\
\hline \multirow{2}{*}{ Audio cassettes } & $\mathrm{n}$ & 2 & 0 & 6 & 1 & 9 \\
\hline & $\%$ & $6.5 \%$ & $0.0 \%$ & $37.5 \%$ & $16.7 \%$ & $9.5 \%$ \\
\hline \multirow{2}{*}{ CD/DVD ROMs } & $\mathrm{n}$ & 0 & 0 & 5 & 3 & 8 \\
\hline & $\%$ & $0.0 \%$ & $0.0 \%$ & $31.3 \%$ & $50.0 \%$ & $8.4 \%$ \\
\hline \multirow{2}{*}{ CD/DVD player } & $\mathrm{n}$ & 0 & 1 & 4 & 1 & 6 \\
\hline & $\%$ & $0.0 \%$ & $11.1 \%$ & $25.0 \%$ & $16.7 \%$ & $6.3 \%$ \\
\hline \multirow{2}{*}{ Audio conferencing tools } & $\mathrm{n}$ & 1 & 1 & 4 & 2 & 8 \\
\hline & $\%$ & $3.2 \%$ & $11.1 \%$ & $25.0 \%$ & $33.3 \%$ & $8.4 \%$ \\
\hline \multirow{2}{*}{ Video conferencing tools } & $\mathrm{n}$ & 0 & 1 & 4 & 2 & 7 \\
\hline & $\%$ & $0.0 \%$ & $11.1 \%$ & $25.0 \%$ & $33.3 \%$ & $7.4 \%$ \\
\hline \multirow{2}{*}{ Computer conferencing tools } & $\mathrm{n}$ & 1 & 1 & 4 & 2 & 8 \\
\hline & $\%$ & $3.2 \%$ & $11.1 \%$ & $25.0 \%$ & $33.3 \%$ & $8.4 \%$ \\
\hline \multirow{2}{*}{ AGREGATED SCORE (MRS) } & $\mathbf{n}$ & 23 & 10 & 47 & 15 & 95 \\
\hline & $\%$ & $8.5 \%$ & $13.0 \%$ & $37.3 \%$ & $30.0 \%$ & $18.2 \%$ \\
\hline $\mathrm{N}$ (Total number of responses) & & 270 & 77 & 126 & 50 & $523(100.0 \%)$ \\
\hline
\end{tabular}

$\chi^{2}$-test: $\chi^{2}=54.04 ; \mathrm{df}=3 ; \mathrm{P}<0.001$. 
Except for some computers in both institutions and CD/DVD ROMs in Douala the provision of the other learning equipment is very inadequate. This indicates that the institutions do not have the financial resources to pay for the needed technology for the programmes. This lack of basic equipment associated with the chosen models of distance education accounts in part for the poor levels of interaction reported earlier in all the programmes (Figure 8).

The overall average degree of ease (22.2\%) with which students' access learning equipment made available by the institutions is extremely dissatisfactory. The highest levels of difficulties (9\%) and (13\%) are reported in Buea and Dschang. The situation in Douala (30\%) and Yaounde I (37\%) though comparatively better is far below average. This means that the needed technological equipment required for the proper functioning of the chosen models in all the programmes is not available. The institutions clearly do not have the means to provide the needed technology equipment for the distance learning programmes.

\section{Discussion}

The study suggests that the multi-media (study centre) model is used by the distance learning programmes in the universities of Buea and Dschang while the Tele; earning (Online) model is used by the distance learning programmes in Douala and Yaounde I. This is confirmed by the percentage usage of all the indicators of the two models in their various programmes.

The distance learning programme in the University of Buea has study centres at the Regional level and one at divisional level where there is a clustered student population. Presently, regional study centres operate in four regions: South-west Region in Buea, Northwest Region in Bamenda, Far North Region in Maroua and the Centre Region in Yaounde. There is a divisional study centre in Kumba. In the programme in Dschang contact activities use to take place at various antennas that were created in centres in various parts of the country until recently

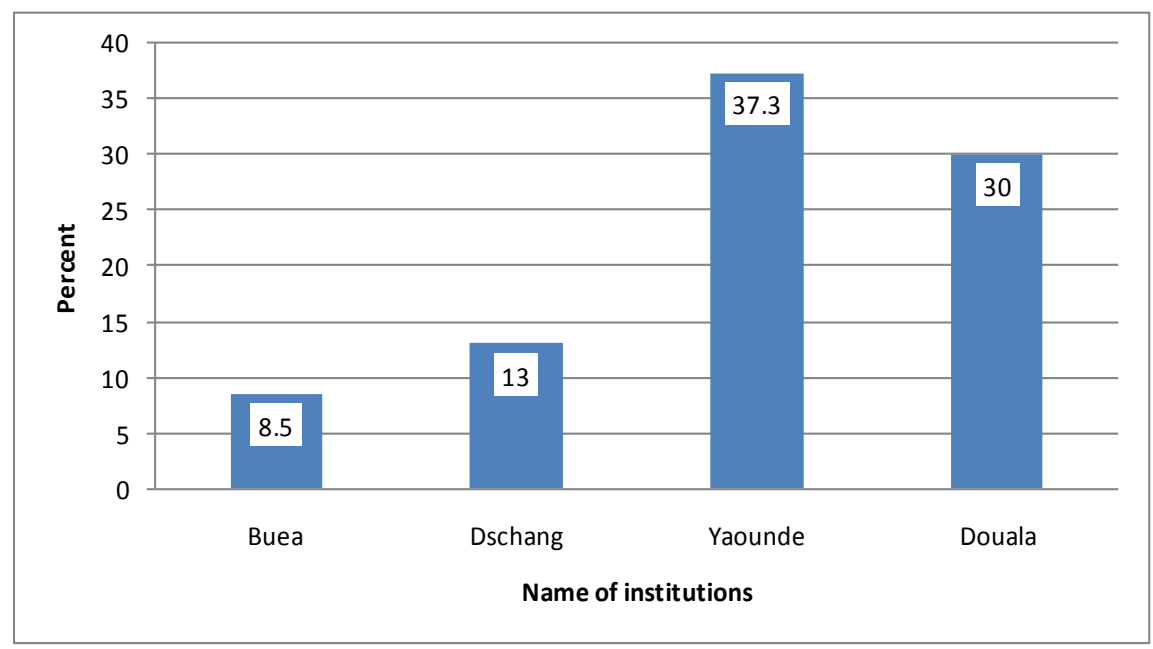

Figure 8. Ease of access to learning equipment at the study center. 
that all contact activities have been relocated to the university campus at scheduled times. The telephone is principally used in both institutions to support learning outside the face-to-face meetings. Therefore, the need to provide for interaction between tutors and students and between students seems to be the main driving force in the provision of contact sessions at study centres. The Universities of Yaounde I and Douala use Email and Learning or Course Management Systems that have been developed to provide a single platform for the integration of components and features for content delivery, communication, and evaluation since computer mediated communication, audio and video conferencing equipment seem to be either insufficient or absent.

Regarding the degree of effectiveness with which each of the distance learning institutions is using its chosen model, the findings on the eight indicators of learner support used in assessing them suggests as follows.

All the universities are providing pre-registration information to students at a very satisfactory rate. This ranges from 59\% in Douala, through 69\% in Buea, to $71 \%$ in Yaounde I and 77\% in Dschang. However, the study highlights students dissatisfaction with the provision of information relating to certain aspects of the progrmmes (the cost of the programmes in Buea, Dschang and Douala; the target audience and end of study qualifications in Yaounde I; the start and end dates in Buea and Douala.

Students' satisfaction with the provision of information relating to the conduct of the courses in the programmes is very positive with satisfaction rates of $81 \%$ in Dschang, 74\% in Buea, and 61\% in Yaounde I. However, students in the programme in Douala expressed dissatisfaction (40\%) with the provision of this information. Irrespective of the positive overall performance in Buea, the study indicates that the administrative capacity of the programme needs to be strengthened as students have difficulties in getting solutions to their administrative problems with a satisfaction level of $45 \%$.

A closer look at the results suggest that in the implementation of the distance learning programmes, Dschang is the most efficient in providing students with course related information registering a satisfaction level of between $56 \%$ to $100 \%$, on all indicators, followed by Buea with a satisfaction level of between $68 \%$ to $94 \%$, on 6 of the 7 indicators, and Yaoundé I with a satisfaction level of between $50 \%$ to $63 \%$ on all indicators. Students in Douala are generally dissatisfied with the provision of information relating to the conduct of the courses of the programme as they express satisfaction with only two (the provision of information on how to get help with course problems and information on students tutors) of the seen indicators of the study.

Consequently, the programme in Douala is the most inefficient in terms of the use of the chosen model to provide students with information needed during the course of their study. The provision of information to students in a manner easily digestible and the flexibility to receive feedback and react promptly is an essential ingredient in any distance learning programme. The development of such 
a fluid information diffusion and management system according to Dirr (1999), reduces attrition, provides for a well-rounded programme, eases students adjustment to college, assist in their intellectual and personal growth, contributing to their academic success. An effective learner support system needs to be efficient in the management and provision of information in a timely manner and flexible enough in the reduction of student problems (Tait, 2000).

\subsection{Satisfaction with Access to Learning Resources Available in the Course}

All the distance learning programmes provide learners with materials, technology and human resources to facilitate student's learning. Consequently, the study indicates that students reported satisfaction with access to the course materials (course materials and course guides) provided by the programmes in Dschang (89\%) and (57\%), Buea (68\%) and (65\%), and Yaounde I (69\%) and (56\%) respectively. Students reported lack of satisfaction with access to the above materials in Douala (33\%) cumulatively. Students in Yaounde I and Douala reported satisfaction with access to library and internet services with satisfaction levels of $69 \%$ and $50 \%$ in Yaounde I and 50\% and 67\% in Douala respectively. Students in Buea and Dschang were less satisfied with the level of access to the above learning resources with satisfaction levels of $34 \%$ in Buea and 22\% in Dschang for library services and $48 \%$ in Buea and 22\% in Dschang for internet resources. Students expressed more satisfaction with access to study centre facilities in Buea (58\%) and Yaounde (50\%) and less satisfaction in Dschang (33\%) and Douala (0\%). Students reported satisfaction with access to tutors and instructors in Buea and Dschang with satisfaction levels of $74 \%$ and $77 \%$ in Buea and $78 \%$ and $89 \%$ in Dschang. Students were less satisfied with access to the above human resources in Yaounde I (50\%) and (44\%) and Douala (33\%) cumulatively.

A critical look at the general results, indicates that the programme in Dschang is the most successful in providing students access to learning resources with an aggregate satisfaction level of $61 \%$, followed by the programmes in Buea with $60 \%$, Yaounde I with 59\% and Douala 40\%, (indicating student satisfaction on only 3 of the 8 indicators). In relation to adopted model the institutions using the multi-media model are more efficient in providing students access to available learning resources than those using the telelearning model.

\subsection{Satisfaction with Interaction in the Course}

Generally, most of the students in all the distance learning programmes expressed dissatisfaction with the interactional strategies used by the various institutions. However, when one examines the results in terms of the model used the results are more positive for institutions using the study centre model than for those using the e-learning model.

In the universities of Buea and Dschang using the study centre model students 
reported satisfaction with three interaction strategies. That is, the use of face-to-face tutorials and feedback on assignments to stimulate and provide student to tutor and student to student interaction and counseling services.

Regarding the university of Yaounde I and Douala using the telelearning model, students reported very low satisfaction rates with two interaction strategies; the use of computer conferencing (50\% respectively, and the use of video conferencing.

\subsection{Extent to which Learning Strategies Help Sustain Students in the Programme}

The findings of the study show that students were most satisfied with learning strategies used by the distance learning programme in Buea and Dschang (using the study centre model) to prevent students from dropping out of the programmes. The levels of satisfaction were between $74 \%$ and $94 \%$ in Buea and between 56\% and 100\% in Dschang. Among the institutions using the telelearning model (Yaounde I and Douala), students reported satisfaction levels of between $50 \%$ to $88 \%$ in Yaounde I and $50 \%$ to $67 \%$ in Douala. .Students in Yaounde I reported dissatisfaction with their ability to prepare and submit assignments regularly (38\%) and with the methods used for assessment while students in Douala were dissatisfied with the development of time management skills (33\%), performance in assignments (33\%), mastering of study skills as distance learner (33\%), and tutors comments on student's assignments (33\%).

Therefore, institutions using the Study centre model (Buea and Dschang) are more effective in the use of learning strategies that sustain learners in their programmes than institution using the telelearning model (Yaounde I and Douala).

\subsection{Usefulness of Counseling in Solving Learning Problems}

Counseling is very important in addressing student's personal and learning problems. Generally, students were satisfied with the provision of counseling services. However, counselling is most effectively used in Dschang (78\%) and Buea and Yaounde I (71\%). The results suggest that the institutions using the Study centre model (Dschang and Buea) are more effective in the use of counseling services than those using the telelearning model (Yaounde I and Douala). The gender related results suggests that male adult students $(75 \%)$ are in greater need for counselling than their female (58\%) counterparts while the age related results indicate that counselling is most useful to young students $(81 \%)$.

\subsection{Ease with Which Students Afford Needed Learning Equipment}

The results suggest that a majority of students in programmes in Buea, Dschang and Douala experience serious difficulties in acquiring the equipment needed for their studies. The greatest level of difficulty (22\%), was reported in Buea, followed by Dschang (30\%) and Douala (36\%). However, half (54\%) of the students in Yaounde I reported their ability to buy 4 (a computer, pay for internet con- 
nection, and buy audio cassettes and DVD/CD players) of the learning equipment needed for their studies. Most students in Dschang (78\%) reported their ability to buy a computer and $50 \%$ of the students in Douala reported their ability to buy CD/DVD players.

The generally manifested inability of students to buy needed learning equipment can partly be explained by the low salaries earned by the students. Most students in Buea earn monthly salaries of between 30,000 to 140,000 thousand francs while students in Yaounde I and Dschang earned salaries of 140,000 thousand francs and above monthly. Therefore, the smooth operation of the selected models is hindered by student's lack of sufficient means to buy the needed learning equipment.

\subsection{Ease of Access to Available Learning Equipment}

Generally it is very difficult to access learning equipment provided by the distance learning institutions because these equipment are either available in insufficient quantities or are not available at all. However, students reported that it is more easy accessing available equipment at the study centres of institutions using the telelearning model than in those using the online model.

\section{Conclusion}

Distance learning institutions of higher learning in Cameroon are using the study centre and online models in delivering their programmes. The study centre model depends primarily on print with face-to-face tutorial and the use of telephone tutorials while the online institutions combine the face-to-face tutorial with minimal use of computer and video conferencing including audio and video cassettes and email.

The provision of learner support is critical to the success of any distance learning programme. Learner support services are provided with more satisfaction in the programmes in Buea and Dschang which have developed their own courseware that is produced locally for student use.

The programmes are in need of current technology driving distance learning in terms of equipment, structures, management, software, knowhow, and trained human resources to enable them increase their levels of effectiveness.

\section{Recommendation}

To address the absence of appropriate infrastructure for and technological equipment at the study centres in order to raise the level of interaction so central in distance learning, the education stakeholders should be sensitized to support government by providing funding or physical or material needs of the programmes. The Ministry of Higher education and the concerned universities should also seek partnerships with other distance learning institutions in order to pool financial, material human and technical resources to enhance the effectiveness of the functioning of their programmes. 


\section{References}

Briner, M. (1990). Constructivism: The Theories. http://curriculum.calstatela.edu/faculty/psparks/theorists//500const.htm

Brown, J. S., Collins A., \& Duguid, P. (1989). Situated Cognition and the Culture of Learning. Education Researcher, 18, 32-42. https://doi.org/10.3102/0013189X018001032

Dirr, P. J. (1999). Putting Principles into Practice; Promoting Effective Support Services for Students in Distance learning Programs; a Report on the Findings of a Survey. Project funded in the U.S. Department of Education's Fund for the Improvement of Postsecondary Education. http://www.wcet.info/project/studentservices

Garrison, R. (2000). Theoretical Challenges for Distance learning in the 21st Century: A Shift from Structural to Transactional Issues. The International Review of Research in Open and Distance Learning, 1, No 1. http://www.irrodl.org/index.php/irrodl/article/viewArticle/2/333

Holmberg, B. (1989). Theory and Practice of Distance Learning. London: Routledge.

Koul, B. N., Valicha, K., \& Murugan, K. (2000). Growth and Philosophy of Distance Education. New Delhi: Berry Art Press.

Lave, J., (1988). Cognition in Practice: Mind Mathematics and Culture in Everyday Life. In J. Lave, \& E. Wenger (Eds.), Situated Learning: Legitimate Peripheral Participation. Cambridge, UK: Cambridge University Press.

Moore, M. (1990). Recent Contributions to the Theory of Distance Education. Open Learning, 5, 10-15. https://doi.org/10.1080/0268051900050303

Moore, M. G. (1991). Editorial: Distance Learning Theory. The American Journal of Distance Learning, 5, 1-6.

Moore, M. G., \& Kearsley, G. (1996). Distance Learning: A Systems View. New York: Wadsworth.

Norman, D. (1993). Things that Make Us Smart. New York: Addison Wesley.

Tait, A. (2000). Planing Student Support for Open and Distance Learning. Open Larning, 15, No. 3.

Peters, O. (1994). Introduction. In D. Keega (Ed.), Otto Peters on Distance Education: The Industrialization of Teaching and Learning (pp. 1-23). London: Routledge.

Peters, O. (n.d.). Concepts and Models of Open and Distance Learning. http://www.c3l.uni-oldenburg.de/cde/found/peter98b.htm

Vygotsky, L. S. (1978) Mind in Society. Cambridge M.A: Harvard University Press.

Wedemeyer, C. A. (1971). Independent Study. In R. Deighton (Ed.), Encyclopedia of Education $I V$ (pp. 548-557). New York: McMillan.

Wedemeyer, C. A. (1977). Independent Study. In A. S. Knowles (Ed.), The International Encyclopedia of Higher Education. Boston, MA: Northeastern University. 